\title{
Large plasmidome of dairy Lactococcus lactis subsp. lactis biovar diacetylactis FM03P encodes technological functions and appears highly unstable
}

\author{
Oscar van Mastrigt, Elisa Di Stefano, Sylviani Hartono, Tjakko Abee and Eddy J. Smid*
}

\begin{abstract}
Background: Important industrial traits have been linked to plasmids in Lactococcus lactis.

Results: The dairy isolate L. lactis subsp. lactis biovar diacetylactis FM03P was sequenced revealing the biggest plasmidome of all completely sequenced and published L. lactis strains up till now. The 12 plasmids that were identified are: pLd1 (8277 bp), pLd2 (15,218 bp), pLd3 (4242 bp), pLd4 (12,005 bp), pLd5 (7521 bp), pLd6 (3363 bp), pLd7 (30,274 bp), pLd8 (47,015 bp), pLd9 (15,313 bp), pLd10 (39,563bp), pLd11 (9833bp) and pLd12 (3321 bp). Structural analysis of the repB promoters and the RepB proteins showed that eleven of the plasmids replicate via the theta-type mechanism, while only plasmid pLd3 replicates via a rolling-circle replication mechanism. Plasmids pLd2, pLd7 and pLd10 contain a highly similar operon involved in mobilisation of the plasmids. Examination of the twelve plasmids of L. lactis FM03P showed that 10 of the plasmids carry putative genes known to be important for growth and survival in the dairy environment. These genes encode technological functions such as lactose utilisation (lacR-lacABCDFEGX), citrate uptake (citQRP), peptide degradation (pepO and pepE) and oligopeptide uptake (oppDFBCA), uptake of magnesium and manganese (2 $\mathrm{mntH}$, corA), exopolysaccharides production (eps operon), bacteriophage resistance ( 1 hsdM, 1 hsdR and 7 different $h s d S$ genes of a type I restriction-modification system, an operon of three genes encoding a putative type II restriction-modification system and an abortive infection gene) and stress resistance ( 2 uspA, cspC and cadCA). Acquisition of these plasmids most likely facilitated the adaptation of the recipient strain to the dairy environment. Some plasmids were already lost during a single propagation step signifying their instability in the absence of a selective pressure.
\end{abstract}

Conclusions: Lactococcus lactis FM03P carries 12 plasmids important for its adaptation to the dairy environment. Some of the plasmids were easily lost demonstrating that propagation outside the dairy environment should be minimised when studying dairy isolates of L. lactis.

Keywords: Lactic acid bacteria, Dairy, Plasmid, Protoplast-induced curing, Functionality, Stability

\section{Background}

Lactococcus lactis is a lactic acid bacterium which is extensively used in food fermentation processes. It is one of the main species used in starter cultures for the production of fermented dairy products, such as cheese, quark, cottage cheese and sour cream [1,2]. L. lactis is naturally present on plants $[3,4]$ and it is proposed that

\footnotetext{
* Correspondence: eddy.smid@wur.nl

Food Microbiology, Wageningen University \& Research, P.O. Box 17, 6700AA, Wageningen, The Netherlands
}

dairy strains have evolved from plant-associated strains transferred to milk via cattle $[1,5-10]$. L. lactis has adapted to the dairy environment by the acquisition of important traits required for the growth on milk, such as lactose catabolism, proteinase activity, citrate utilisation and bacteriophage resistance. Analysis of genomes of $L$. lactis has shown that these traits are often encoded by genes located on plasmids [11].

Plasmids are mobile, self-replicating extrachromosomal DNA molecules which can be lost and acquired in 
response to changing environmental conditions. This behaviour facilitates their distribution among bacteria occupying the same ecological niche. Depending on the environmental conditions, plasmids could have beneficial or adverse effects for the recipient strain. They could give the bacteria the ability to grow better on particular nutrients or survive better under harsh conditions, but at the same time they can be a metabolic burden by either replication of the plasmids or by expression of the plasmid-encoded genes [12].

In this study, the complete nucleotide sequences of twelve plasmids of the dairy isolate of $L$. lactis subsp. lactis biovar diacetylactis FM03P are presented, together with analysis of the putative biological functions that were assigned to them. Plasmid-cured variants were made by protoplast-induced curing to confirm some of the putative functions and to demonstrate the impact of the plasmids on growth.

\section{Results and discussion Sequencing}

Lactococcus lactis subsp. lactis biovar diacetylactis FM03P has been isolated from 10-week-old Samsø cheese. Its genome has been sequenced using a combination of an Illumina HiSeq2500 and PacBio RS instrument as previously described [13]. This revealed the complete sequence of the chromosome and 7 plasmids, designated pLd1 to pLd7. Subsequent next-generation sequencing attempts of L. lactis FM03-V1, a single colony isolate of a culture of L. lactis FM03P, using only Illumina revealed the sequence of 5 other plasmids, designated pLd8 to pLd12. The different sequencing attempts have been summarised in (Additional file 1: Figure S1). Using PCR and analysis by gel electrophoresis, we confirmed the presence of all 12 plasmids in parent strain $L$. lactis FM03P (Additional file 1: Figure S2). The obtained sequences of $\mathrm{pLd} 8$ to pLd12 were not present in the raw unassembled PacBio and Illumina reads obtained from strain FM03P demonstrating that these plasmids were already lost during propagation.

The genome of L. lactis subsp. lactis biovar diacetylactis FM03P contains a chromosome of $2.43 \mathrm{Mbp}$ with a $\mathrm{G}+\mathrm{C}$ content of $35.3 \%$ and 12 plasmids with sizes of 8.3, 15.2, 4.2, 12.0, 7.5, 3.4, 30.3, 47.0, 15.3, 39.6, 9.8, and $3.3 \mathrm{kbp}$ and $\mathrm{G}+\mathrm{C}$ contents of $34.8,34.1,35.6,33.5,33.6$, $33.8,35.2,35.3,35.2,34.9,33.0$, and $33.2 \%$, respectively (Fig. 1). The obtained plasmid sequences were annotated using RAST [14] after which the annotation was manually curated and analysed in detail including their replication mechanisms and mobilisation properties.

\section{Replication}

Plasmids replicate independently from the chromosome using plasmid-encoded Rep proteins. Plasmids in lactococci replicate using either rolling-circle replication (RCR) or theta-type replication [15]. The replication mechanism as well as the sequence of the replication protein and the origin of replication affect the stability of the plasmids, their copy number and their compatibility. RCR plasmids replicate via the synthesis of ssDNA intermediates, and these plasmids are usually small in size, have multiple copies and are incompatible with other RCR plasmids [16, 17]. Sequence homology of the replication initiator protein and the presence of a double-stranded origin of replication $(d s o)$ indicated that pLd3 is the only RCR plasmid in L. lactis FM03P. On pLd2 we found a gene encoding a protein that had high similarity to the N-terminal part of RepB which is normally encoded on RCR plasmids of the type pMV158, but the C-terminal end was found to be missing.

Theta plasmids are more common in lactococci and a single bacterial cell can contain multiple theta plasmids [18]. Based on the homology of the replication initiator protein and structural motifs in the was concluded that all plasmids except pLd3 replicate with a theta-type mechanism (Additional file 1: Figures S3 and S4). On plasmid pLd8 two repB genes are located of which the second replicon (with the repB2 gene) seems to be functional as it is highly similar to the replicons of other plasmids. In contrast, in the promoter of repB1 the inverted repeat $\mathrm{IRb}$ is missing and the C-terminus of the predicted RepB1 protein is quite different from the other predicted RepB proteins (including RepB2). Both the $\operatorname{rep} B$ genes on pLd10 seem to be functional. The DNA sequences of the repB genes on plasmids pLd2 and pLd9 and their promoters are 100\% identical. This could cause incompatibility of these plasmids and could result in plasmid loss $[15,19]$. This may also explain why plasmid pLd9 was not found in the first sequencing attempt. We also observed spontaneous loss of plasmid pLd2 during continuous chemostat cultivation, while pLd9 was kept (data not shown).

\section{Mobilisation}

Plasmids can carry conjugation or mobilisation regions that increase their spread in the population via conjugation events. Conjugative plasmids are self-transmissible, while mobilisable plasmids are only transmissible in the presence of additional conjugative functions [20]. To determine if plasmids were transmissible, the plasmid sequences were searched for known conjugation and mobilisation regions. Plasmids pLd2, pLd7 and pLd10 showed a highly similar (> 97\%) operon of 4 genes involved in mobilisation of the plasmid. The DNA sequence of these operons in pLd2, pLd7 and pLd10 is 96, 97 and 98\% similar to the mobilisation region of pNZ4000, respectively, which was demonstrated to be functional [21]. Plasmid pNZ4000 was found in Lactococcus lactis and carries genes necessary for the production of exopolysaccharides. The oriT 


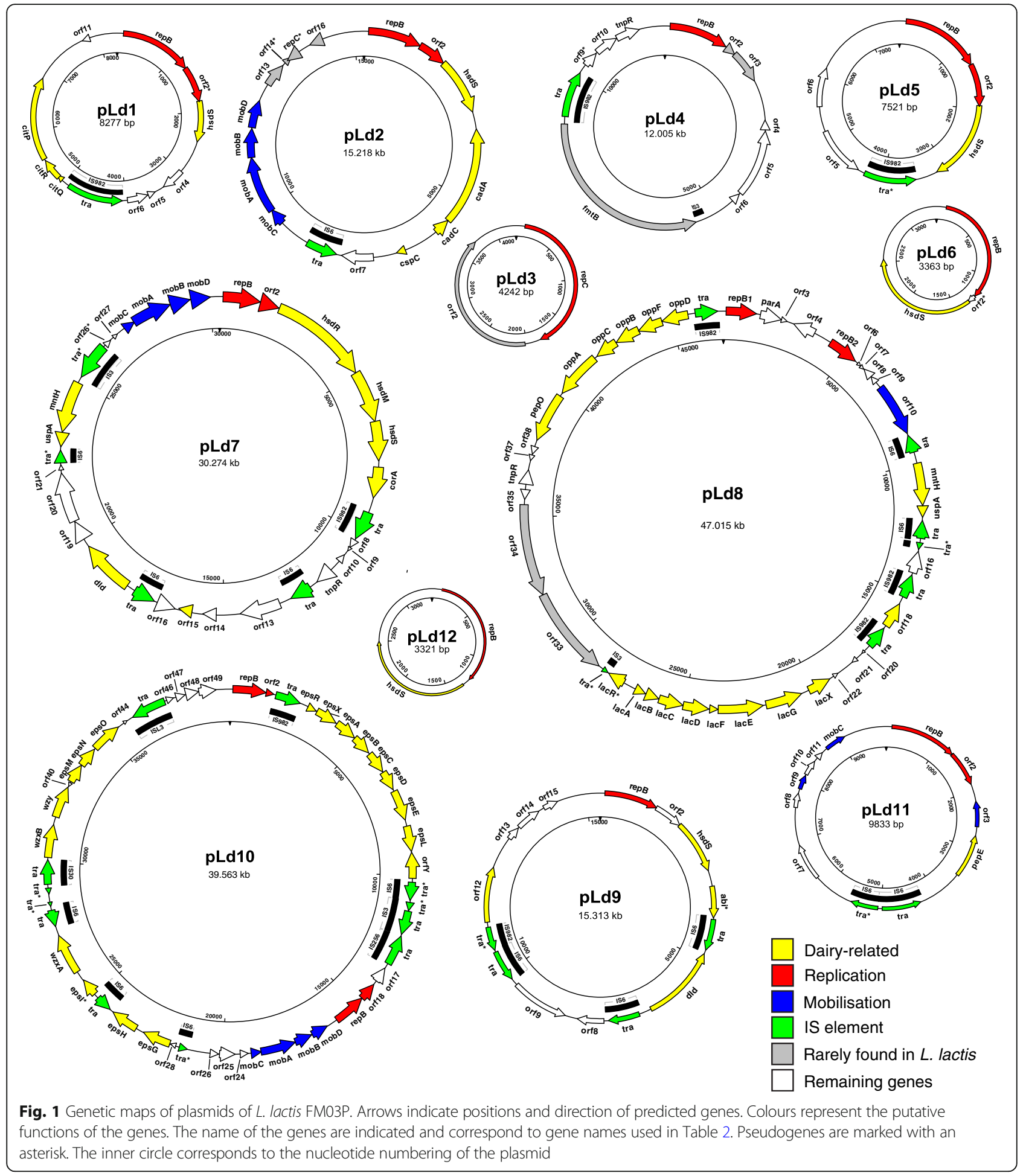

sequences, essential for plasmid mobilisation, of pLd2, pLd7 and pLd10 are highly similar to the functional oriT1 sequence of pNZ4000 (Fig. 2) and all plasmids carry a $m o b A$ gene encoding a relaxase that is involved in nicking at the nic sites of the oriT sequences. Plasmids pLd2, pLd7 and pLd10 also carry mobC which is present but not annotated in pNZ4000. The genes $m o b C$ and $m o b B$, of which the start codon overlaps with the stop codon of $m o b A$, most likely encode accessory proteins for MobA $[22,23]$. The function of $m o b D$, designated $m o b C$ in pNZ4000, remains to be elucidated. Recently, the nucleotide sequence of plasmid p229C of L. lactis 229 has been 


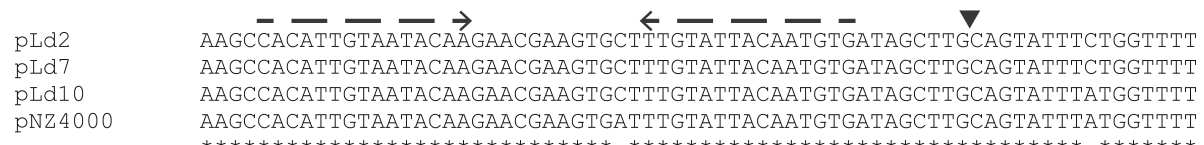

Fig. 2 Multiple sequence alignment of oriT regions of plasmids pLd2, pLd7, pLd10 and pNZ4000 [21]. The inverted repeat is shown with dashed arrows and the arrowhead indicates the nic site. The asterisks below indicate identical nucleotides in all four sequences

published [24]. This plasmid is remarkably similar to plasmid pLd7 (> 99.9\%), while the other plasmids show no or limited similarity. Both strains are isolated from the dairy environment and the mobilisation operon might have increased the transfer rate of this plasmid within the dairy environment. In addition to the mobilisation operons, pLd11 carries 3 genes (orf3, orf9 and mobC) encoding proteins which may be involved in mobilisation. Moreover, pLd8 carries a gene encoding a putative conjugal transfer protein (nickase) of the MobA-MobL family. In contrast to the described genes on pLd2, pLd7 and pLd10, these genes are not part of a large mobilisation gene cluster.

\section{Plasmid-encoded functions}

On the 12 plasmids, we identified and annotated in total 203 putative genes or fragments thereof, which corresponds to $7.4 \%$ of the total number of putative genes present in the entire genome (Table 1). Based on homology with other proteins, putative functions were ascribed to $74 \%$ of the plasmid encoded genes. Of all genes $10 \%$ were pseudogenes containing frameshifts, a premature stop codon or truncations. An overview of all the genes in the plasmidome of L. lactis FM03P is given in Fig. 3 and their putative functions are given in Table 2. In the coming sections a selection of genes encoding functions that could enhance growth and survival of the bacteria and/or encode technological properties are described in more detail.

\section{Substrate uptake and utilisation}

To thrive in particular environments, microorganisms require specific transporters and metabolic pathways to take up substrates from the environment and use them for growth. Therefore, the presence of genes encoding particular transporters or metabolic enzymes indicate adaptation to a specific environments. To investigate if L. lactis FM03P was adapted to the dairy environment, we searched the plasmid sequences for genes involved in utilisation of the main carbon and energy sources found in bovine milk: citrate, lactose and proteins.

Citrate utilisation is characteristic for the biovariety diacetylactis of Lactococcus lactis that contains a plasmid-encoded citQRP operon. In L. lactis FM03P, this operon is located on plasmid pLd1, which is $99 \%$ identical to lactococcal plasmids pCRL1127 and pIL2. The citP gene is encoding a citrate permease enabling the host to take up divalent citrate from the environment [25]. Citrate utilisation results in the generation of a proton motive force in L. lactis [26] and at the same time increases the $\mathrm{pH}$ of the environment [27]. Citrate

Table 1 Summary of plasmid statistics and the putative genes

\begin{tabular}{|c|c|c|c|c|c|}
\hline & \multirow{2}{*}{$\begin{array}{l}\text { Size } \\
\text { (bp) }\end{array}$} & \multirow{2}{*}{$\begin{array}{l}G+C \\
\text { content } \\
(\%)\end{array}$} & \multicolumn{3}{|c|}{ Total no. of: } \\
\hline & & & ORFs & Pseudogenes $^{\mathrm{a}}$ & Homolog with known function \\
\hline pLd1 & 8277 & 33.8 & 11 & $1(0)$ & 7 \\
\hline pLd2 & 15,218 & 35.6 & 16 & $3(0)$ & 14 \\
\hline pLd3 & 4242 & 33.6 & 2 & 0 & 1 \\
\hline pLd4 & 12,005 & 34.8 & 11 & 1 & 4 \\
\hline pLd5 & 7521 & 33.5 & 6 & 0 & 5 \\
\hline pLd6 & 3363 & 34.1 & 3 & 1 & 2 \\
\hline pLd7 & 30,274 & 35.2 & 31 & $3(2)$ & 23 \\
\hline pLd8 & 47,015 & 35.3 & 45 & $3(2)$ & 32 \\
\hline pLd9 & 15,313 & 35.2 & 15 & $2(1)$ & 12 \\
\hline pLd10 & 39,563 & 34.9 & 49 & $5(4)$ & 40 \\
\hline pLd11 & 9833 & 33.0 & 12 & $1(1)$ & 8 \\
\hline pLd12 & 3321 & 33.2 & 2 & 0 & 2 \\
\hline Total & 195,945 & & 203 & $20(10)$ & 150 \\
\hline
\end{tabular}

${ }^{a}$ Values in parentheses indicate number of pseudogenes in IS elements 


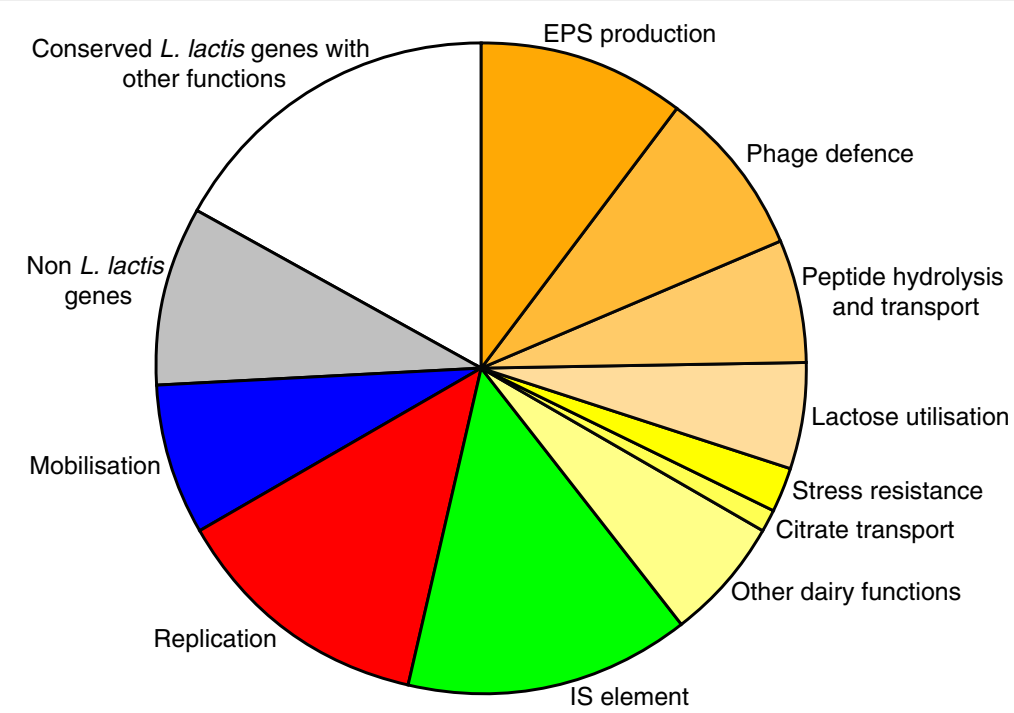

Fig. 3 Overview of the putative functions of plasmid-encoded genes in L. lactis FM03P. The sum of the sizes of the genes within a category relative to the total size of all plasmid genes was used. The orange to yellow categories represent dairy functions. Other dairy functions include genes for uptake of magnesium and manganese (cor $\mathrm{A}$ and $\mathrm{mntH}$ ), D-lactate dehydrogenases ( $\mathrm{dld}$ ), and a C4-dicarboxylate transporter. Non L. lactis genes include the genes that are rarely found in L. lactis. Conserved L. lactis genes with other functions consist of all the putative genes which are regularly found in $L$. lactis and encode hypothetical proteins or proteins with functions that did not fit into the other categories

utilisation also has been linked to the production of acetoin and diacetyl. These buttery aromas are important flavour compounds in dairy products. Both citQ and citR are involved in the regulation of expression if citP $[28,29]$. The gene citP is mainly expressed at low $\mathrm{pH}$ (around 5.5) when the abundance of divalent citrate is maximal $[30,31]$, minimising the metabolic burden of maintaining this plasmid.

Genes involved in lactose uptake and utilisation are found on plasmid pLd8, which contains the lacR-lacABCDFEGX operon for lactose uptake via a phosphotransferase system (PTS) and utilisation via the tagatose-6-phosphate pathway. As described for L. lactis IL1403 [32], L. lactis FM03P also contains the chromosomal-encoded Leloir pathway for lactose utilisation. The presence of both pathways in one strain might give this strain a competitive advantage by fast uptake and utilisation of lactose. Interestingly, the LacR protein might not be functional due to a 40 amino acids deletion at the C-terminus, most likely caused by an IS element insertion in the lacR gene. LacR is a transcriptional repressor of the lac operon and deletion of the lacR gene has been shown to increase the activity of the lac promoter both during growth on glucose and lactose [33, 34]. Therefore, a non-functional LacR might increase the maximum lactose utilisation rate.

Genes involved in utilisation of proteins, or more specifically oligopeptides, are found on plasmid pLd8, which contains the $p e p O$ gene encoding a neutral endopeptidase and the complete oppDFBCA gene cluster encoding the oligopeptide permease (Opp) system [35]. All of these genes are also encoded on the chromosome with a high similarity in amino acid sequence (>99\%), except for oppA which only has $87 \%$ similarity to its chromosomal homolog. Plasmid pLd11 carries a pepE gene encoding a putative aspartyl dipeptidase $\mathrm{E}$, which does not have a chromosomal homolog. The opp and pep genes are required, in combination with the extracellular protease PrtP, for utilisation of the milk caseins as nitrogen source $[35,36]$. The extracellular protease is often plasmid encoded by prtP and prtM [37]. Interestingly, the prtP and prtM genes are not found in $L$. lactis FM03P and this strain does not show a caseinolytic phenotype (data not shown). Presence of the $p e p E$, pepO and oppDFBCA gene cluster and absence of the prtP and prtM genes could give the strain an advantage when growing in combination with a protease-positive $\left(\mathrm{prt}^{+}\right)$strain in milk, in particular at high cell densities [38]. Only the $\mathrm{prt}^{+}$strain secretes the protease to hydrolyse the milk caseins, thereby investing energy in production of this protein, while the protease-negative $\left(\mathrm{prt}^{-}\right)$strain can use the peptides generated by the protease without having the burden of protease expression. This combination of $\mathrm{prt}^{+}$and $\mathrm{prt}^{-}$strains is found in many dairy starter cultures, for instance in the Ur starter culture [39]. The presence of pepO and opp genes on both the chromosome and plasmid pLd8 could result in faster utilisation of the peptides depending on the copy number of the plasmid and the regulation of expression of the $p e p O$ and opp genes.

\section{Phage resistance by restriction-modification systems}

An important technological property that is often carried by plasmids is the resistance to bacteriophage infections via the type I restriction-modification system comprising of 
Table 2 Overview of the putative genes and their putative functions

\begin{tabular}{|c|c|c|c|}
\hline Plasmid & Gene & Putative function & Best homolog found in: \\
\hline \multirow[t]{11}{*}{$\overline{p L d 1}$} & repB & Replication initiator protein & \\
\hline & orf2* & Replication-associated protein & \\
\hline & hsdS & Type I restriction-modification system specificity subunit $S$ & \\
\hline & orf4 & Hypothetical protein & \\
\hline & orf5 & Hypothetical protein & \\
\hline & orf6 & Hypothetical protein & \\
\hline & tra & Transposase IS982 family & \\
\hline & citQ & Leader peptide CitQ & \\
\hline & citR & Translational regulator & \\
\hline & citP & Citrate transporter & \\
\hline & orf11 & Hypothetical protein & \\
\hline \multirow[t]{16}{*}{ pLd2 } & $\operatorname{rep} B$ & Replication initiator protein & \\
\hline & orf $2^{*}$ & Replication-associated protein & \\
\hline & hsdS & Type I restriction-modification system specificity subunit S & \\
\hline & cadA & Cadmium-transporting ATPase & \\
\hline & $\operatorname{cadc}$ & Cadmium efflux system accessory protein & \\
\hline & $\operatorname{csp} C$ & Cold shock protein & \\
\hline & orf7 & Serine/threonine protein phosphatase & \\
\hline & tra & Transposase IS6 family & \\
\hline & mobc & Mobilisation protein & \\
\hline & mobA & Mobilisation protein & \\
\hline & mobB & Mobilisation protein & \\
\hline & mobD & Mobilisation protein & \\
\hline & orf13 & HXXEE domain-containing protein & Streptococcus thermophilus \\
\hline & orf14* & XRE family transcriptional regulator & Streptococcus thermophilus \\
\hline & $\operatorname{rep} C^{*}$ & Replication initiator protein & Lactobacillus farciminis \\
\hline & orf16 & Hypothetical protein & Enterococcus faecium \\
\hline \multirow[t]{2}{*}{ pLd3 } & repC & Replication initiator protein & \\
\hline & orf2 & Hypothetical protein & Lactobacillus reuteri \\
\hline \multirow[t]{11}{*}{ pLd4 } & repB & Replication initiator protein & \\
\hline & orf2 & Hypothetical protein & Enterococcus faecalis \\
\hline & orf3 & Hypothetical protein & Enterococcus faecalis \\
\hline & orf4 & Hypothetical protein & \\
\hline & orf5 & Hypothetical protein & \\
\hline & orf6 & Hypothetical protein & \\
\hline & $f m t B$ & Peptidoglycan-binding protein & Streptococcus thermophilus \\
\hline & tra & Transposase IS982 family & \\
\hline & orf9* & DNA-directed DNA polymerase & \\
\hline & orf10 & Hypothetical protein & \\
\hline & $\operatorname{tnp} R$ & Resolvase & \\
\hline \multirow[t]{4}{*}{ pLd5 } & rep $B$ & Replication initiator protein & \\
\hline & orf2 & Replication-associated protein & \\
\hline & hsdS & Type I restriction-modification system specificity subunit S & \\
\hline & tra & Transposase IS982 family & \\
\hline
\end{tabular}


Table 2 Overview of the putative genes and their putative functions (Continued)

\begin{tabular}{|c|c|c|c|}
\hline Plasmid & Gene & Putative function & Best homolog found in: \\
\hline & orf5 & Hypothetical protein & \\
\hline & orf6 & Site-specific integrase & \\
\hline \multirow[t]{3}{*}{ pLd6 } & rep $B$ & Replication initiator protein & \\
\hline & orf $2^{*}$ & Hypothetical protein & \\
\hline & hsds & Type I restriction-modification system specificity subunit $\mathbf{S}$ & \\
\hline \multirow[t]{31}{*}{ pLd7 } & repB & Replication initiator protein & \\
\hline & orf2 & Replication-associated protein & \\
\hline & $h s d R$ & Type I restriction-modification system specificity subunit $R$ & \\
\hline & $h s d M$ & Type I restriction-modification system specificity subunit M & \\
\hline & hsds & Type I restriction-modification system specificity subunit $\mathbf{S}$ & \\
\hline & corA & Magnesium transporter & \\
\hline & tra & Transposase IS982 family & \\
\hline & orf8 & Hypothetical protein & \\
\hline & orf9 & Hypothetical protein & \\
\hline & orf10 & Hypothetical protein & \\
\hline & $\operatorname{tnp} R$ & Resolvase & \\
\hline & tra & Transposase IS6 family & \\
\hline & orf13 & MFS transporter & \\
\hline & orf14 & Acetyltransferase & \\
\hline & orf15 & Polysaccharide biosynthesis protein & \\
\hline & orf16 & Hypothetical protein & \\
\hline & tra & Transposase IS6 family & \\
\hline & $d l d$ & D-Lactate dehydrogenase & \\
\hline & orf19 & Hypothetical protein & \\
\hline & orf20 & Hypothetical protein & \\
\hline & orf21 & Hypothetical protein & \\
\hline & $\operatorname{tra}^{*}$ & Transposase IS6 family & \\
\hline & uspA & Universal stress protein & \\
\hline & $m n t H$ & Manganese transporter & \\
\hline & $\operatorname{tra}^{*}$ & Transposase IS3 family & \\
\hline & $\operatorname{orf26} 6^{*}$ & integrase/recombinase & \\
\hline & orf27 & Hypothetical protein & \\
\hline & mobc & Mobilisation protein & \\
\hline & mobA & Mobilisation protein & \\
\hline & mobB & Mobilisation protein & \\
\hline & mobD & Mobilisation protein & \\
\hline \multirow[t]{8}{*}{ pLd8 } & repB1 & Replication initiator protein & \\
\hline & parA & Chromosome partitioning protein & \\
\hline & orf3 & Hypothetical protein & \\
\hline & orf4 & Serine protease & \\
\hline & repB2 & Replication initiator protein & \\
\hline & orf6 & Hypothetical protein & \\
\hline & orf7 & Hypothetical protein & \\
\hline & orf8 & Hypothetical protein & \\
\hline
\end{tabular}


Table 2 Overview of the putative genes and their putative functions (Continued)

\begin{tabular}{|c|c|c|c|}
\hline Plasmid & Gene & Putative function & Best homolog found in: \\
\hline & orf9 & Hypothetical protein & \\
\hline & orf10 & Nickase & \\
\hline & tra & Transposase IS6 family & \\
\hline & $m n t H$ & Manganese transporter & \\
\hline & uspa & Universal stress protein & \\
\hline & tra & Transposase IS6 family & \\
\hline & $\operatorname{tra} a^{*}$ & Transposase IS6 family & \\
\hline & orf16 & AAC(3) family $\mathrm{N}$-acetyltransferase & \\
\hline & tra & Transposase IS982 family & \\
\hline & orf18 & C4-dicarboxylate $A B C$ transporter & \\
\hline & tra & Transposase IS982 family & \\
\hline & orf20 & Hypothetical protein & \\
\hline & orf21 & Hypothetical protein & \\
\hline & orf22 & Large-conductance mechanosensitive channel & \\
\hline & $\operatorname{lac} x$ & Hypothetical protein & \\
\hline & lacG & 6-phospho-beta-galactosidase & \\
\hline & lacE & PTS lactose transporter subunit IIBC & \\
\hline & lacF & PTS lactose transporter subunit IIA & \\
\hline & $\operatorname{lacD}$ & Tagatose 1,6-diphosphate aldolase & \\
\hline & lacC & Tagatose-6-phosphate kinase & \\
\hline & $l a c B$ & Galactose-6-phosphate isomerase subunit LacB & \\
\hline & lacA & Galactose-6-phosphate isomerase subunit LacA & \\
\hline & $\operatorname{lac} R^{*}$ & Lactose repressor & \\
\hline & $\operatorname{tra}{ }^{*}$ & Transposase IS3 family & \\
\hline & orf33 & Type II restriction modification system & Leuconostoc mesenteroides \\
\hline & orf34 & Type II restriction modification system & Leuconostoc mesenteroides \\
\hline & orf35 & Hypothetical protein & \\
\hline & $\operatorname{tnp} R$ & Resolvase & \\
\hline & orf37 & Hypothetical protein & \\
\hline & orf38 & Hypothetical protein & \\
\hline & pepO & Neutral endopeptidase & \\
\hline & oppA & Peptide-binding protein & \\
\hline & $o p p C$ & Peptide $A B C$ transporter permease & \\
\hline & $o p p B$ & Peptide $A B C$ transporter permease & \\
\hline & $o p p F$ & Oligopeptide transport ATP-binding protein & \\
\hline & oppD & Oligopeptide transport ATP-binding protein & \\
\hline & tra & Transposase IS982 family & \\
\hline \multirow[t]{7}{*}{ pLd9 } & repB & Replication initiator protein & \\
\hline & orf2 & Hypothetical protein & \\
\hline & hsdS & Type I restriction-modification system specificity subunit $\mathrm{S}$ & \\
\hline & $a b i^{*}$ & Abortive phage resistance protein & \\
\hline & tra & Transposase IS6 family & \\
\hline & $d l d$ & D-lactate dehydrogenase & \\
\hline & tra & Transposase IS6 family & \\
\hline
\end{tabular}


Table 2 Overview of the putative genes and their putative functions (Continued)

\begin{tabular}{|c|c|c|c|}
\hline Plasmid & Gene & Putative function & Best homolog found in: \\
\hline & orf8 & Hypothetical protein & \\
\hline & orf9 & MFS transporter & \\
\hline & tra & Transposase IS6 family & \\
\hline & $t r a^{*}$ & Transposase IS982 family & \\
\hline & orf12 & Amidohydrolase of peptidase M20 family & \\
\hline & orf13 & Hypothetical protein & \\
\hline & orf14 & Site-specific integrase & \\
\hline & orf15 & Integrase-associated protein & \\
\hline \multirow[t]{36}{*}{ pLd10 } & repB1 & Replication initiator protein & \\
\hline & orf2 & Replication-associated protein & \\
\hline & tra & Transposase IS982 family & \\
\hline & epsR & XRE family transcriptional regulator & \\
\hline & epsX & Polysaccharide biosynthesis protein & \\
\hline & epsA & Tyrosine protein kinase transmembrane modulator & \\
\hline & epsB & Tyrosine protein kinase & \\
\hline & epsC & Tyrosine protein phosphatase & \\
\hline & eps $D$ & Undecaprenyl-phosphate galactosephosphotransferase & \\
\hline & epsE & Group 1 glycosyltransferase & \\
\hline & epsL & Exopolysaccharide biosynthesis protein & \\
\hline & orfy & LytR family transcriptional regulator & \\
\hline & $\operatorname{tra}^{*}$ & Transposase IS6 family & \\
\hline & tra & Transposase IS3 family & \\
\hline & tra & Transposase IS3 family & \\
\hline & tra & Transposase IS256 family & \\
\hline & orf17 & XRE family transcriptional regulator & \\
\hline & orf18 & Replication-associated protein & \\
\hline & repB2 & Replication initiator protein & \\
\hline & mobD & Mobilisation protein & \\
\hline & $\operatorname{mob} B$ & Mobilisation protein & \\
\hline & mobA & Mobilisation protein & \\
\hline & mobc & Mobilisation protein & \\
\hline & orf24 & Hypothetical protein & \\
\hline & orf25 & Integrase & \\
\hline & orf26 & Hypothetical protein & \\
\hline & $\operatorname{tra}^{*}$ & Transposase IS6 family & \\
\hline & orf28 & Hypothetical protein & \\
\hline & eps $G$ & Glycosyltransferase family 2 protein & \\
\hline & eps $H$ & Glycosyltransferase family 2 protein & \\
\hline & tra & Transposase IS6 family & \\
\hline & eps $\|^{*}$ & Glycosyltransferase & \\
\hline & WZXA & Flippase & \\
\hline & tra & Transposase IS6 family & \\
\hline & $\operatorname{tra}^{*}$ & Transposase & Lactobacillus/Oenococcus/Enterococcus \\
\hline & $\operatorname{tra}{ }^{*}$ & Transposase & Lactobacillus \\
\hline
\end{tabular}


Table 2 Overview of the putative genes and their putative functions (Continued)

\begin{tabular}{|c|c|c|c|}
\hline Plasmid & Gene & Putative function & Best homolog found in: \\
\hline & tra & Transposase IS30 family & Lactobacillus \\
\hline & $w z \times B$ & Flippase & Lactobacillus \\
\hline & wzy & Polymerase & Lactobacillus \\
\hline & orf 40 & Hypothetical protein & \\
\hline & eps $M$ & Glycosyltransferase family 2 protein & Lactobacillus \\
\hline & $\operatorname{eps} N$ & Glycosyltransferase & Lactobacillus \\
\hline & epsO & Glycosyltransferase family 1 protein & Lactobacillus \\
\hline & orf44 & DUF4411 domain-containing protein & Lactobacillus plantarum \\
\hline & tra & Transposase ISL3 family & Lactobacillus \\
\hline & orf46 & Hypothetical protein & Lactobacillus \\
\hline & orf 47 & Hypothetical protein & \\
\hline & orf 48 & Hypothetical protein & \\
\hline & orf49 & Resolvase & \\
\hline \multirow[t]{12}{*}{ pLd11 } & rep $B$ & Replication initiator protein & \\
\hline & orf2 & Replication-associated protein & \\
\hline & orf3 & Relaxase/mobilisation nuclease domain protein & \\
\hline & pepE & Peptidase E & \\
\hline & tra & Transposase IS6 family & \\
\hline & $t r a^{*}$ & Transposase IS6 family & \\
\hline & orf7 & DUF1919 domain-containing protein & \\
\hline & orf8 & DUF3883 domain-containing protein & \\
\hline & orf9 & Relaxase & \\
\hline & orf10 & Hypothetical protein & \\
\hline & orf11 & Hypothetical protein & \\
\hline & mobc & Mobilisation relaxosome protein & \\
\hline \multirow[t]{2}{*}{ pLd12 } & rep $B$ & Replication initiator protein & \\
\hline & hsdS & Type I restriction-modification system specificity subunit $\mathbf{S}$ & \\
\hline
\end{tabular}

Putative functions that could be beneficial in the dairy environment are shown in bold. Pseudogenes are indicated with an asterisk. The species that contains the best homolog is given of genes that are rarely found in L. lactis

three subunits. HsdS and HsdM are both necessary for methyltransferase activity, while $\mathrm{HsdR}$ is required in addition to the HsdS-HsdM complex for restriction of foreign' DNA that is not methylated [40]. The HsdS subunit contains two variable target recognition domains (TRDs) that determine the target sequence specificity of both the restriction and modification activities of the complex [40, 41]. The variable domains are flanked by conserved regions required for specific associations with the other subunits and for maintaining the relative positions of the two TRDs [40]. In L. lactis FM03P the three subunits of this system (HsdR, HsdM and HsdS) are all encoded once on the chromosome. On 7 out of the 12 plasmids other HsdS subunits are found. The protein sequences of all HsdS proteins were aligned with MAFFT (Fig. 4). Most of the HsdS proteins contained two variable regions flanked by highly conserved regions as expected. However, the HsdS protein encoded on plasmid pLd1 is not complete. The hsdS gene carried by pLd1 is about half of the size, most likely due to a deletion of 500 to 600 nucleotides. Interestingly, the second variable region of the HsdS proteins of $\mathrm{pLd} 2$ and $\mathrm{pLd} 5$ are identical and also 97\% similar to pLd7, while the first variable regions do not show significant homology to each other. Similarly, the first variable regions of the HsdS proteins of pLd2, pLd9 and pLd12 are identical, while the second variable region of pLd2 does not show significant homology to those of pLd9 and pLd12. The high similarities of one of the variable regions suggest homologous recombination events as also found for plasmids pAH33 and pAH82 [42]. This could result in new R/M specificities.

In addition to the many $h s d S$ genes, on pLd7 also HsdR and HsdM subunits are encoded. These proteins have a low homology to their chromosomal counterparts (41\% and $34 \%$, respectively), although the C-terminus of HsdM is quite similar to its chromosomal counterpart. As Schouler and co-authors [43] described before, the 


\begin{tabular}{|c|c|}
\hline & YI - \\
\hline pLd9 & LRFPGFTDDWEERKLGSLTTVVRG--ASPRP IQDPKWF DKESDIGWLRIADVTEQNGR Y YHLEQH I SKLGQEKT \\
\hline di2 & DDSVKKKVPELRFPGFTDDWEERKLGSLTTVVRG--ASPRPI QDPKWF DKESDI GWLRIADVTEQNGRI YHLEQH ISKLGQEKT \\
\hline d2 2 & AKIDDSVKKKVPELRFPGFTDDWEERKLGSLTTVVRG--ASPRPIQDPKWFDKESDIGWLRIADVTEQNGRIYHLEQHISKLGQEKT \\
\hline $\mathrm{d} 55$ & AKIDDSVKKKVPELRFKGFTDDWEERKLGELSNIVGG--GTPSTSNSEYW---DGDI DWYAPAEIGEQR-YVSKSKKTI TELGLKKS \\
\hline d7 & 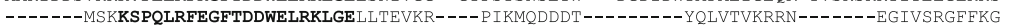 \\
\hline d6 & AKI DDSVKKKVPELRFPGFTDDWEERKLGELTTS F SG--GTPSAGNSSYY---KGDIPF IRSGE INSDK-----TELFLTEAGLKSS \\
\hline pLd1 & AKIDDSVKKKVPELRFKGFTDDWEERKLGEVGKTKSG-IGFPDAQQG-----GKQVTPFYKVSDMNNPGNEVVMMNANNYASDSQLK \\
\hline & JQRAVAFKSLQE-TDDNFF--AQLLRSPIVQNTLKASS \\
\hline & ---- LLS IAATV-GKPVVNYVKTG---VHDGEL-IFLNPT-FEREFM--FQWLEMFRPKW--QKYGQ \\
\hline d12 & -RVLTEPHL-------LLSIAATV-GKPVVNYVKTG---VHDGFL-IFLNPT-FEREFM--FQWLEMFRPKW--QKYGQPGSQVNLN \\
\hline $\mathrm{d} 2$ & -RVLTEPHL------LLSIAATV-GKPVVNYVKTG---VHDGFL-IFLNPT-FEREFM--FQWLEMFRPKW--QKYGQPGSQVNLN \\
\hline 15 & ARILPVGTV-------LFTSRAGI-GNTAILGKEAT---TNQGFQSIVPNPNKLDSYFI--YSRTNELKRYG--EVTGAGSTFVEIS \\
\hline 7 & -QILVKNYFELHAGDYLI I KRQVVHGANGIVPKDMEGAIVSNEYLVSVGNKN-ITTDFLTI I SKLPIMYKMFFLSSYGIDIEKLVFN \\
\hline do & KMVSVGDI-------LYALYGATSGEVGISQINGA---INQAILAIKP \\
\hline d1 & KWNP INPQ-------NSGVVFAKVGAAIFLDRKRI---VDTSELI DNNMMSYLFDSSWNRYFGKTLFEKLRLSI IFAQVGALPSFNG \\
\hline & \\
\hline & LVRNQEIVLP-NYKEC \\
\hline d112 & ELVRNQEIVLP-NYKEQQKIGSFFKQLDETIZ \\
\hline d2 2 & SELVRNQEIVLP-NYKEQQKIGSFFKQLDNTITLHQRKLDLLKEQKKGYLQKMFPKNGAKVPELRFAGFA \\
\hline & GKQMSKMS IMVP-ELSEQKKIGSFFEQLDNTIALHQRKLDLLKEQKKGY \\
\hline 7 & KDWKKREIS I P-SLQEQDRISSFFKQLDDTIVLHQRKLDLLKEQKKGYLQKMF PKNGAKVPELRFAGFADDWEERKLSSMTNYKNGK \\
\hline & IVKNLVLKVP-NFEEQKKIGAFFKQLDDTITLHQRKLDLLKEQKKG \\
\hline tal & DVEDIKVMIP-EESEQKMIGDMFEKLDDIIALHQ RK \\
\hline & \\
\hline & GDHTVSLYK------------ PK-----SPFFVATDG \\
\hline & 'VSLYK--------------PK-----SPFFVATD \\
\hline d2 & HEDKQS - TSGKLELINLNS IS ISGGLKHSGKF I DEADD-TLQKDDLVMILSDVGHGDLLGRVALI PE-----DDRFVLNQRVALLRP \\
\hline 5 & SHEDKQS-TSGKLELINLNS IS ISGGLKHSGKFIDEADD-TLQKDDLVMI LSDVGHGDLLGRVALIPE-----DDRFVLNQRVALLRP \\
\hline id7 & GHEDKQS - TI GKFELINLNS I S I SGGLKHSGKF I DEADD-TLQKDDLVMI LSDVGHGDLLGRVALI PE-----DDRFVLNQRVALLRP \\
\hline pLd6 & NRLPKDSLTNGDVP------YVVAQTKNDGVFTKIARG-TLDYNGKPMKLF---PGNS ISFS I DNPEAMFYRNAEFYTSNIMRVIHE \\
\hline pLd1 & \\
\hline & \\
\hline & \\
\hline d12 & DNF-DGDYLYTTLE--RYKPEPQGYKRHFTILKNQDV----WFTENMEEQQKIGSFFKQLDDTIALHQRKLDLLKEQKKGFLQKMFV \\
\hline & NTTADPQFLFSY INAHQYYFKAQGAGMSQLNISKGSVENF I SFVP I I EEQKKIGAFFKQLDDTITLHQRKLDLLKEQKKGFLQKMFF \\
\hline$d s$ & NTTADPQFLFSY INAHQYYFKAQGAGMSQLN I SKGSVENF I SFVP I I EEQKKI GAFFKQLDDTI TLHQRKLDLLKEQKKGFLQKMFF \\
\hline d & NATADPQFLFSY INAHQYYFKAQGAGMSQLN I SKGSVENF I SFVPI I EEQKKI GTFFKQLDNTITLHQRKLDLLKEQKKGFLQKMFV \\
\hline & DHLTHEQYVF ILENMKRF---IRGYDWSR-KFSGPVVSNLEYLQPSEEEQQKIGSFFKQLDDTIDLHQRKLDLLKEQKKGYLQKMFV \\
\hline 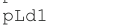 & \\
\hline
\end{tabular}

Fig. 4 Alignment of predicted amino acid sequences of HsdS proteins encoded by genes of Lactococcus lactis FM03P. The conserved regions are shown with boldface letters [43]. Shaded boxed show the identical amino acids sequence in the variable regions of different HsdS proteins

C-terminal parts of the HsdM subunits of different families have a common sequence that could be involved in the association of HsdM with HsdS. Therefore, the different HsdM and HsdR variants found on the chromosome and the plasmids in combination with the many different plasmid encoded HsdS subunits can form an effective recombination system for broadening the target specificity of the system.

In addition to the type I R/M system, plasmid pLd8 harbours orf33, orf34 and orf35 encoding a putative type II restriction-modification system. A similar operon is found in Leuconostoc mesenteroides LK-151 (90\%) and in the strains JM3, SK110 and N41 of Lactococcus lactis. orf34 is predicted to encode a type IIG restriction enzyme/N6-adenine DNA methyltransferase according to the restriction enzymes database REBASE [44], which contains both a methylase and recognition domain (pfam12950) according to the SMART database [45]. However, no restriction domain was found in the protein encoded by orf34. The restriction domain is most likely part of the protein encoded by orf33. This protein contains a putative phospholipase D (PLD) domain (pfam13091), a SNF2 ATPase domain (pfam00176), a DEAD-like helicase domain and a helicase C-terminal domain (pfam00271) according to the SMART database. The PLD domain is the metal-independent catalytic site in type IIS restriction endonucleases [46] and might also catalyse the restriction. Notably, the predicted domains in the proteins encoded by orf33 and orf 34 are similar to the domains found in the recently identified Class I DISARM system for bacteriophage defence in which the methylase was also predicted to be of the IIG type [47], although they do not share a similar organisation.

Finally, plasmid pLd9 carries an $a b i$ gene encoding a putative abortive infection system. The first 642 nucleotides of this gene are $100 \%$ identical to a gene encoding the characterised abortive infection system Abi-859 [48]. However, the last 207 nucleotides are missing in pLd9 due to an insertion of a mobile element, so this system might not be functional.

\section{Exopolysaccharide (EPS) production}

Exopolysaccharides are thought to have several functions including protection against low-moisture environments and toxic compounds (e.g. bile salts and hydrolysing enzymes, metal ions and antibiotics), colonisation and preventing phage infection [49]. However, in the dairy industry the most important function of EPS is that due to its water-binding capacity, it may improve the rheological properties of the fermented product by affecting the viscosity, syneresis, firmness and taste perception [50]. Plasmid pLd10 carries 18 eps genes encoding putative proteins involved in polysaccharide production via the Wzy-dependent pathway. A typical eps gene cluster 
in L. lactis consists of the 6 highly conserved genes epsR, eps $X$, eps $A$, eps $B$, eps $C$ and eps $D$ at the $5^{\prime}$ end, a variable region including genes encoding a polymerase $(w x y)$, a flippase $(w z x)$, one or more glycosyltranferases and/or other polymer-modifying enzymes and the conserved genes epsL and $\operatorname{orf} Y$ at the 3' end [50]. These genes are usually transcribed as a single mRNA [21]. Interestingly, in pLd10 the eps genes are distributed over two clusters and in between these clusters a replication and a mobilisation operon are located, which are flanked by IS elements (Fig. 1). The first cluster consists of: i) the epsR gene encoding an XRE family transcriptional regulator; ii) the conserved gene eps $X$ with unknown function; iii) the phosphoregulatory module consisting of eps $A B C$; iv) eps $D$ encoding an undecaprenyl-phosphate galactosephosphotransferase which catalyses the first step in the assembly of the EPS basic repeating unit (i.e. addition of galactose-1-phosphate to the lipid-phosphate carrier); v) epsE encoding a putative glycosyltranferase; and finally (vi) epsL and $\operatorname{orf} Y$ with an unknown and regulator function, respectively. The second cluster consists of $6 \mathrm{pu}$ tative glycosyltransferase genes (epsH, epsI, epsJ, epsO, epsP, epsQ) of which epsI is most likely not functional, 2 putative flippases for export $(w z x A$ and $w z x B)$ and a putative polymerase $(w z y)$. On the chromosome, two other eps clusters are found (Fig. 5). The first cluster has a typical organisation of $L$. lactis eps operons (epsRXABCD - epsL-orfY), while the second cluster has a typical Lactobacillus eps cluster. This operon starts with epsA encoding a LytR transcriptional regulator followed directly by the phosphoregulatory module (epsBCD) and does not contain eps $X$, epsL and orf $Y$.

\section{Cation transport}

Cation transporters play an important role in growth and survival of microorganisms i) by protecting against toxic heave metals, like cadmium, ii) by providing essential metals, like magnesium, or iii) by providing metals that increase stress survival, like manganese. Several cation transporters were found on the plasmids of L. lactis FM03P.

Plasmid pLd2 carries genes encoding the proteins CadA and CadC, which are $>99.8$ and $100 \%$ similar to CadA and CadC encoded on plasmids pAH82 of L. lactis DPC220 and pND302 of L. lactis M71 and on the chromosome of Streptococcus thermophiles 4134, respectively [51-53]. The cadCA genes have been shown to provide resistance towards cadmium and zinc in both S. thermophiles and L. lactis $[51,53]$. CadC is a transcriptional repressor which binds to its own promoter region [54]. At high cadmium concentrations, $\mathrm{CadC}$ is released from its promoter resulting in the production of cadCA transcript and the expression of cadA [51]. CadA is an ATPase of the P-type catalysing the efflux of cadmium and zinc [55]. The gene cadD, which is located on the chromosome, also encodes a cadmium transporter with $44 \%$ similarity in amino acid sequence to the plasmid encoded (pRW001) CadD of Staphylococcus aureus [56].

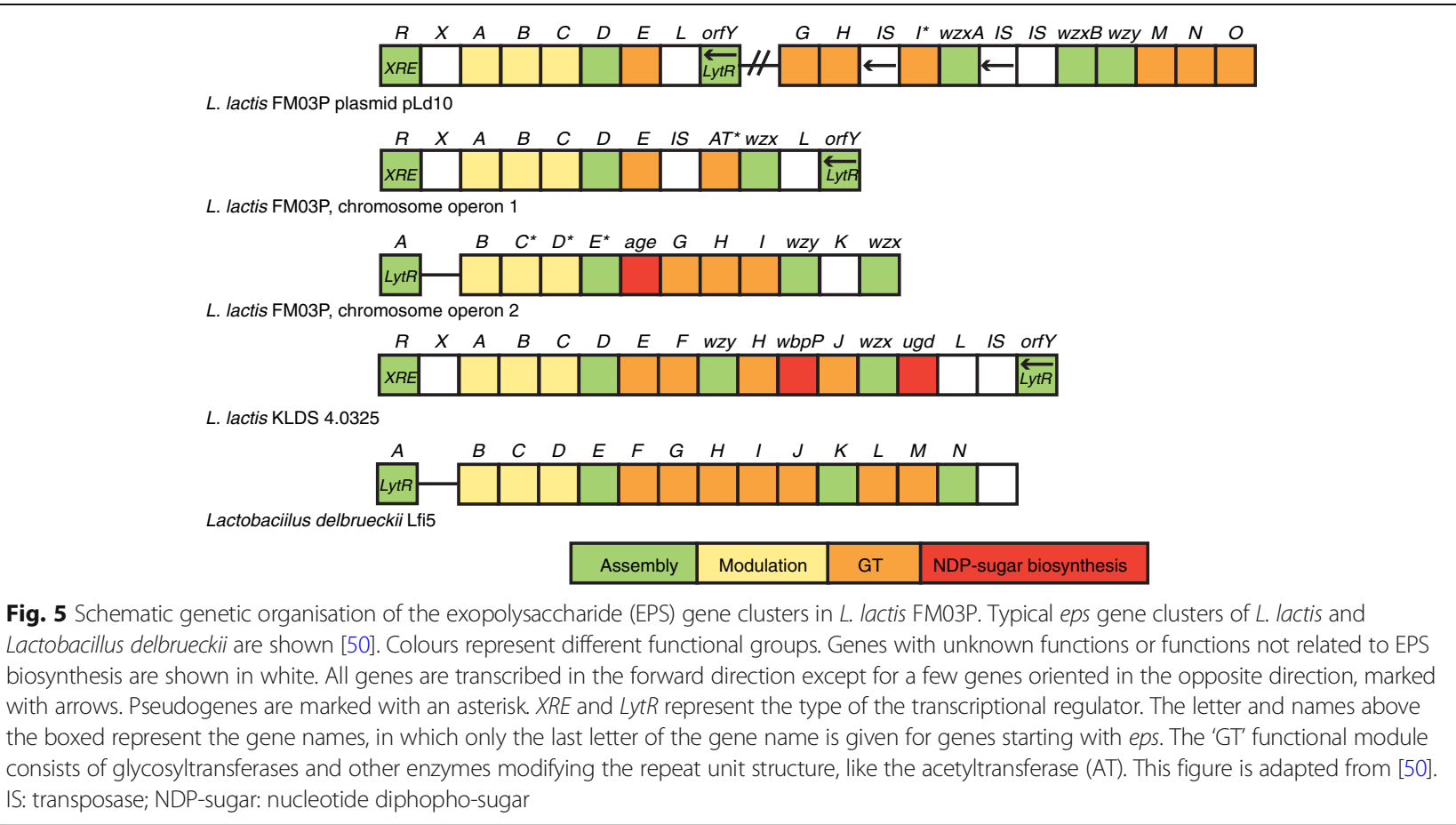


On plasmid pLd7 we found the corA gene encoding a CorA family transporter, which is expected to be the main $\mathrm{Mg}^{2+}$ uptake system in bacteria but might transport other cations like cobalt or nickel as well [57]. The CorA protein on pLd7 is $99 \%$ identical to the CorA protein found on plasmid pSK11P of L. lactis SK11. On the chromosome three other CorA family transporters are found as well as two other $\mathrm{Mg}^{2+}$ transporting ATPases. The best match of all these proteins only had $27 \%$ homology to CorA of pLd7. Kehres et al. [58] observed a high degree of diversity in sequences within the CorA family even within one species and argued that members within the CorA family might have functions other than $\mathrm{Mg}^{2+}$ transport. This may also be the case for some of the CorA proteins found in the genome of L. lactis FM03P.

The third cation transporter on plasmids of L. lactis FM03P is the manganese transporter $\mathrm{MntH}$, which belongs to the Nramp family of transporters for divalent metal ions. $\mathrm{Mn}^{2+}$ ion is an important trace metal required for growth and survival of many bacteria [59]. Several species of lactic acid bacteria accumulate $\mathrm{Mn}^{2+}$ to scavenge toxic oxygen species, especially superoxide radicals $\left(\cdot \mathrm{O}_{2}\right)$. This enables the bacteria to survive oxidative stress conditions [59]. Therefore, it is expected that the presence and activity of this transporter could enhance growth in environments with a low manganese concentration and increase survival towards oxidative stress. Plasmid pLd7 and pLd9 encode similar MntH proteins which are 99\% homologous and belong to class $\mathrm{C}$ of the MntH proteins [60]. The chromosome of L. lactis FM03P harbours three operons that encode manganese transporters: i) a $m n t H$ gene of class $C \beta$, which contains a 344 bp deletion compared to the mntH C $\beta$ gene of $L$. lactis subsp. lactis ATCC 11454 [60], ii) a $m n t H$ gene of class B with $99 \%$ identity to $m n t H$ B of L. lactis subsp. lactis ATCC 11454 [60], and iii) a $m t s B C A$ operon encoding an $\mathrm{ABC}$ transporter for manganese. The $m n t H$ genes on the plasmids most likely take over the role of the disrupted chromosomal mntH $\mathrm{C} \beta$ gene.

\section{Stress resistance}

Besides the potential oxidative stress resistance provided by $\mathrm{MntH}$, there are universal stress proteins (UspA) encoded by genes on pLd7 and pLd 9 and a cold shock protein CspC encoded on pLd2. This CspC protein is identical to the CspC protein of L. lactis MG1363 [61]. Furthermore, orf22 carried by pLd8 encodes a putative large-conductance mechanosensitive channel which acts as osmotic release valve in response to a hypoosmotic shock preventing cell lysis [62].

\section{Antibiotic resistance}

Plasmid pLd8 carries orf16 encoding a putative aminoglycoside 3-N-acetyltransferase, which catalyses the acetylation of aminoglycoside antibiotics at the 3-amino group and thereby this gene is potentially involved in resistance towards these antibiotics [63]. BLAST analysis revealed highly similar genes (>99\% similarity), which are often found on plasmids in L. lactis, for instance in plasmids pJM3B, pSK11L, pC43 pJM2C, pUC06B, pJM4E, pUC109B, p158C, pCIS8, pJM1A and pUC08A. All these plasmid have in common that they are large $(>47 \mathrm{~kb})$ and carry the lacR-la$c A B C D F E G X$ operon for lactose uptake and utilisation and the several oligopeptide transporters.

\section{Miscellaneous beneficial functions}

Other functions encoded by genes on the plasmids that might be beneficial for the host are the putative FAD-dependent D-lactate dehydrogenases on pLd7 and pLd9, which are both $99 \%$ similar to the plasmid encoded putative $\mathrm{D}$-lactate dehydrogenase from L. lactis SK11. Siezen et al. [64] suggested that D-lactate dehydrogenase could play a role in D-lactate utilisation in aerobic cultures, which could increase the external $\mathrm{pH}$ and the conversion to acetate leads to ATP production. However, Tanous et al. [65] did not find D-LDH activity in pGdh442-containing strains, which carry a highly similar dld gene, nor were they capable of growing on M17 containing D-lactate as carbon source. Plasmid pLd8 carries orf18 encoding a C4-dicarboxylate ABC transporter, which function is to transport dicarboxylates such as aspartate, malate, fumarate, succinate and oxaloacetate. Finally, plasmid pLd7 and pLd9 both carry a gene encoding a transporter of the major facilitator superfamily.

\section{New genes}

The plasmids found in L. lactis FM03P carry several genes that are rarely found before in L. lactis, which could indicate horizontal gene transfer events. BLASTP analysis of the amino acid sequence of the predicted protein encoded by orf 2 on plasmid pLd3 gave mainly hits from Lactobacillus reuteri $(<29 \%$ similar in amino acids) and contained a DUF3552 domain with unknown function. On pLd4 the $f m t B$ gene, encoding a putative peptidoglycan-binding protein, has the highest homology to Streptococcus thermophilus strain B59671, although the homology only covers $60 \%$ of the gene. Both the orf 2 and the $f m t B$ gene encode large proteins (569 and 1217 amino acids, respectively), account for a large fraction of the plasmids ( 40.3 and $30.4 \%$, respectively), and are located on the only two plasmids which do not carry other genes with known dairy functions. The genes orf33 and orf34 on pLd8 were homologous to genes of Leuconostoc mesenteroides LK-151 encoding a putative type IIG restriction-modification system. Many genes in the eps operon on pLd10 (especially all genes from tra to orf46; Table 2) were most similar to Lactobacillus species and 
not found in Lactococcus species. Finally, various small (pseudo) genes were found which had the highest homology to species other than L. lactis. These include orf13, orf14, repC and orf16 on pLd2, which are most similar (>96\%) to genes found in Streptococcus, Lactobacillus and Enterococcus and orf 2 and orf3 on pLd4, which are similar to genes of Enterococcus faecalis (99 and 97\%, respectively).

\section{Protoplast-induced curing}

To determine the effect of plasmid content on the growth performance, plasmid-cured variants were made by protoplast-induced curing. After cells were harvested, the cell wall was degraded with lysozyme. Subsequently, protoplasts were regenerated on plates and the plasmid content of random selected colonies was analysed by PCR targeting genes on each plasmids followed by gel electrophoresis. The obtained variants are shown in Table 3.

\section{Plasmid loss in non-dairy environments}

The plasmids carry several genes important for growth in a dairy environment, but in non-dairy environments the plasmids have to be maintained with limited benefits and plasmid-cured variants might arise. Some plasmids were already lost during a single propagation step in either M17 supplemented with glucose or chemically-defined medium containing lactose showing that these plasmids were segregationally unstable in laboratory conditions in the absence of a selection pressure (e.g. bacteriophages, lactose, peptides) (Table 3). To determine the effect of the plasmid content on the growth of L. lactis in a non-dairy environment, the obtained plasmid-cured variants were grown in LM17 and the optical density at $600 \mathrm{~nm}$ was monitored. The growth curves significantly differed between the variants showing that the plasmid content did affect the growth in M17 (Fig. 6a). The highest maximum optical density was found for variant FM03-V1, which only lost plasmid pLd7 (OD 1.1). Variants 48, 49 and 50 had the same maximum growth rate (Fig. 6b) but reached a slightly lower maximum OD (between 0.91 and 0.96). These three variants all lost plasmids pLd4, pLd5 and pLd6, indicating that one of these plasmids might carry a gene which resulted in the higher OD. The growth curve of the parent strain FM03P was similar to variants 48, 59 and 50, but the maximum growth rate could not be estimated using the two-fold dilution method due to flocculation of this variant in M17. The remaining five variants reached a much lower maximum optical density and also grew slower (Fig. 6). Both variant 47 and 63 lost plasmid pLd8 carrying the lacR-lacABCDFEGX operon involved in lactose uptake and utilisation. Therefore, the drop in the growth rate in these variants at an optical density of approximately 0.25 could be caused by limited lactose utilisation and suggests that the lacR-lacABCDFEGX operon is functional when present. Variant 3, 5 and 51 were all growing much slower throughout the cultivation. Variant 3 and 5 are the only variants missing plasmid pLd 10 carrying the eps genes, while variant 51 is the variant with the lowest number of plasmids since it has lost plasmids pLd4, pLd5, pLd6, pLd7, pLd8, pLd9, pLd11 and pLd12.

Additionally, growth performance of variants 48 and 50 , the latter carrying plasmid pLd2 containing the cadCA operon, was determined in co-cultures in M17 supplemented with $0.5 \%$ glucose and $35 \mu \mathrm{M}$ cadmium. Variant 50 dominated the populations after 27 generations (68\%) which shows that $\mathrm{pLd} 2$ provided a competitive advantage in the presence of $35 \mu \mathrm{M}$ cadmium. This is in line with the slightly higher maximal growth rates of variant 50 compared to that of variant 48 in the presence of cadmium (data not shown).

\section{Conclusions}

In the past, important industrial traits have been linked to plasmids in L. lactis. Carrying twelve plasmids, L. lactis FM03P has the biggest plasmidome of all completely

Table 3 Variants of Lactococcus lactis FM03P with different plasmids contents that were obtained in this study

\begin{tabular}{llll}
\hline L. lactis variant & Cured plasmids & Plasmid content & Isolated from \\
\hline FM03P & - & pLd1,2,3,4,5,6,7,8,9,10,11,12 & Sams $\varnothing$ cheese \\
3 & $\mathrm{pLd} 4,5,10$ & $\mathrm{pLd} 1,2,3,6,7,8,9,11,12$ & Protoplast-induced curing \\
5 & $\mathrm{pLd} 4,10,11$ & $\mathrm{pLd} 1,2,3,5,6,7,8,9,12$ & Protoplast-induced curing \\
47 & $\mathrm{pLd} 8,11$ & $\mathrm{pLd} 1,2,3,4,5,6,7,9,10,12$ & Overnight culture \\
48 & $\mathrm{pLd} 2,4,5,6,7$ & $\mathrm{pLd} 1,3,8,9,10,11,12$ & Chemostat culture \\
49 & $\mathrm{pLd} 2,3,4,5,6,7$ & $\mathrm{pLd} 1,8,9,10,11,12$ & Protoplast-induced curing \\
50 & $\mathrm{pLd} 4,5,6,7$ & $\mathrm{pLd} 1,2,3,8,9,10,11,12$ & Protoplast-induced curing \\
51 & $\mathrm{pLd} 4,5,6,7,8,9,11,12$ & $\mathrm{pLd} 1,2,3,10$ & Protoplast-induced curing \\
63 & $\mathrm{pLd} 3,4,8,11,12$ & $\mathrm{pLd} 1,2,5,6,7,9,10$ & Protoplast-induced curing \\
FM03-V1 & $\mathrm{pLd} 7$ & $\mathrm{pLd} 1,2,3,4,5,6,8,9,10,11,12$ & Chemostat culture \\
\hline
\end{tabular}

Variants 47, 48 and FM03-V1 were isolated by plating on LM17 agar plates 


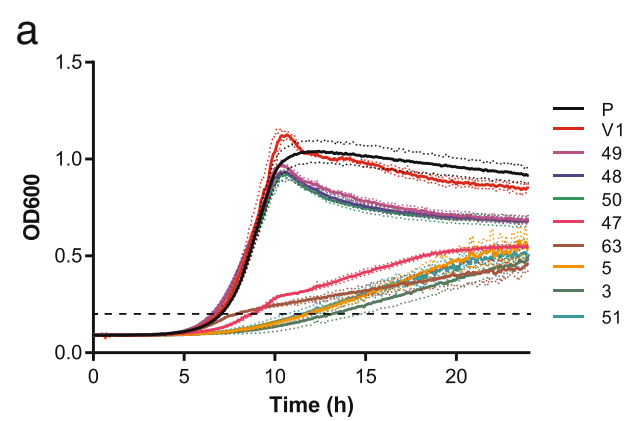

$\mathrm{b}$

6 Growth of plasmid-cured variants of L. lactis FMOzP in LMiz. a Growth curves of the plasmid-cured variants. Dotted lines represent the standard deviation of representative biological duplicates. The dashed line represents an OD600 of 0.2, which was used as threshold to determine the time to detection. b Maximum growth rate as function of the total plasmid size calculated using the two-fold dilution method. Numbers near the symbols correspond to the different plasmid-cured variants. The maximum growth rate of the parent strain FM03P could not be estimated using the two-fold dilution method due to flocculation affecting the optical density measurement and thus the time to detection and is therefore omitted. Error bars represent the standard deviation of biological triplicates

sequenced and published L. lactis strains up till now. Some of its plasmids were already lost during a single propagation step showing that the plasmids can be easily lost during propagation in a non-dairy environment. Because we directly sequenced the strain after it was isolated from cheese, the risk of plasmid loss was minimised. Examination of the twelve plasmids of L. lactis FM03P showed that 10 of the plasmids carry genes known to be important for the growth and survival in the dairy environment. These genes encode functions such as lactose and citrate utilisation, degradation and uptake of peptides, exopolysaccharide production, cation transport and bacteriophage and stress resistance. This shows that the plasmids play an important role in the adaptation of this strain to the dairy environment. Two plasmids, pLd3 and pLd4, did not carry any genes that are known to be linked to the dairy environment, but both do harbour a large gene with unknown function that has not been found before in L. lactis and may have a function relevant for dairy processing.

\section{Methods}

\section{Strain and media}

Lactococcus lactis subsp. lactis biovar diacetylactis FM03P, which has been isolated from 10-weeks-old Samsø cheese using Nickels and Leesment medium [66], was used in this study as well as several variants with a different plasmid content (Table 3). These variants were made by protoplast-induced curing or isolated from cultures of L. lactis FM03P. Phenotypic characterisation of the variants started always with streaking the variants on M17 agar plates [67] supplemented with either $0.5 \%(w / v)$ glucose or lactose. After incubation for 2 days at $30{ }^{\circ} \mathrm{C}$ a single colony was inoculated in M17 supplemented with $0.5 \%$ lactose or glucose and grown overnight at $30{ }^{\circ} \mathrm{C}$.

\section{Whole genome sequencing Sequencing of FM03P}

L. lactis FM03P was plated on M17 agar plates supplemented with $0.5 \%$ lactose (LM17) and incubated for 2 days at $30{ }^{\circ} \mathrm{C}$. A single colony was inoculated in LM17 broth and incubated overnight at $30{ }^{\circ} \mathrm{C}$. Subsequently, genomic DNA was extracted using the $\mathrm{Wizard}^{\circledR}$ genomic DNA purification kit (Promega, USA), sequenced using an Illumina HiSeq 2500 and a PacBio RS instrument, do novo assembled into contigs and scaffolds and closed by PCR and Sanger sequencing. A more detailed explanation of the method can be found in the genome announcement of L. lactis subsp. lactis biovar diacetylactis FM03 [13]. In addition to the complete chromosomal sequence, 7 plasmids were found, which were defined as complete circular contigs with a origin of replication and which could be targeted in a PCR.

\section{Sequencing of FM03-V1 and the plasmids pLd8, pLd9, pLd10, pLd11 and pLd12}

L. lactis FM03-V1, a single colony isolate of a culture of FM03P, was pre-cultured as described above. Subsequently, genomic DNA was extracted using the DNeasy Blood \& Tissue kit (Qiagen, Germany) according to the manufacturer's procedure, sequenced using an Illumina HiSeq 2500 instrument (total 2.3 million quality-filtered paired-end reads and average coverage of 211 times) and de novo assembled into contigs using VelvetOptimiser 1.1.0 (k-mer of 83). The contig sequences were compared to the obtained sequence of L. lactis FM03P, of which only plasmids pLd1 to pLd7 were known at that time. Unmapped contigs with a high coverage were further assembled into scaffolds and closed by PCR and Sanger sequencing. The obtained complete circular sequences are designated plasmids pLd8, pLd9, pLd10, pLd11 and pLd12. 


\section{Protoplast-induced curing}

Protoplasts of $L$. lactis FM03P were prepared in Tris- $\mathrm{HCl}$ magnesium chloride sucrose buffer ( $\mathrm{pH} 8.0$ ) according to Fujita et al. [68] with some modifications. Briefly, L. lactis was grown in LM17, harvested in mid-exponential phase by centrifugation ( $5 \mathrm{~min}, 6000 \times g)$, washed twice with $30 \mathrm{mM}$ Tris- $\mathrm{HCl}$ buffer $(\mathrm{pH}$ 8.0) and resuspended in a buffer for the lysozyme treatment to degrade the cell wall (30 mM Tris- $\mathrm{HCl}, 3 \mathrm{mM} \mathrm{MgCl} 2,20 \%$ sucrose, $100-$ $1000 \mu \mathrm{g} / \mathrm{ml}$ lysozyme, $\mathrm{pH} 8.0$ ). After incubation at $37{ }^{\circ} \mathrm{C}$ for $10,60,120$ or $180 \mathrm{~min}$, protoplast were regenerated by plating appropriate dilutions of treated samples on regeneration medium (LM17 agar supplemented with $20 \%$ sucrose). After incubation at $30{ }^{\circ} \mathrm{C}$ for 48 to $72 \mathrm{~h}$, regenerated colonies were picked and screened for their plasmid content.

\section{Screening for plasmid content}

To determine the plasmid content of the variants, DNA was extracted from bacterial cultures using the DNeasy
Blood \& Tissue kit (Qiagen, Germany) according to the manufacturer's procedure excluding the RNAse step. Subsequently, unique sequences of each plasmid were amplified in PCR reactions using specific primer sets (Table 4). A primer set targeting the chromosome was used as positive control for the DNA extraction. The PCR reaction mixture of $50 \mu \mathrm{l}$ contained $1 \mu \mathrm{l}$ purified genomic DNA, $0.2 \mathrm{mM}$ dNTPs (Thermo Scientific, USA), 0.4 $\mu \mathrm{M}$ of forward and reverse primer, $5 \mu \mathrm{l}$ of $10 \times$ Taq buffer $+\mathrm{MgCl}_{2}$ (Thermo Scientific, USA) and $2 \mathrm{U}$ Taq polymerase (Thermo Scientific, USA). The PCR program started with an initial denaturation cycle at $94{ }^{\circ} \mathrm{C}$ for $5 \mathrm{~min}$, followed by 25 cycles of $94{ }^{\circ} \mathrm{C}$ for $30 \mathrm{~s}, 58{ }^{\circ} \mathrm{C}$ for $20 \mathrm{~s}$ and $72{ }^{\circ} \mathrm{C}$ for $45 \mathrm{~s}$ and a final extension cycle at $72{ }^{\circ} \mathrm{C}$ for $7 \mathrm{~min}$. For plasmids pLd7, pLd8, pLd9, pLd10, pLd11 and pLd12 annealing temperatures were increased to $68,60,62,63,63$ and $60{ }^{\circ} \mathrm{C}$, respectively. PCR amplicons were examined by gel electrophoresis in $1 \%$ agarose gels stained with $\mathrm{SYBR}^{\circ} \mathrm{Safe}$ DNA gel

Table 4 Primer sequences used to detect plasmids in L. lactis FM03P

\begin{tabular}{|c|c|c|c|c|}
\hline \multirow{2}{*}{$\begin{array}{l}\text { Target } \\
\text { Chromosome }\end{array}$} & \multicolumn{2}{|c|}{ Sequence $\left(5^{\prime}-->3^{\prime}\right)$} & \multirow{2}{*}{$\begin{array}{c}\text { Amplicon } \\
254\end{array}$} & \multirow{2}{*}{$\begin{array}{l}\operatorname{Tm}\left({ }^{\circ} \mathrm{C}\right) \\
65.2\end{array}$} \\
\hline & FW & TTAATTCAACCTGGAGACACAGTCTTAG & & \\
\hline & Rv & СTATCAGCGATTTCACGGAACTTAG & & 65.6 \\
\hline \multirow[t]{2}{*}{ pLd1 } & FW & GCATTGACGGCTGTTGTAAT & 209 & 62.5 \\
\hline & Rv & AGCAGATTCCCGAGGATAAC & & 62.0 \\
\hline \multirow[t]{2}{*}{ pLd2 } & FW & AATGGGCCGAAGGTTCTATT & 285 & 63.4 \\
\hline & Rv & CAGGAACCGATTCTCCTGTTA & & 62.9 \\
\hline \multirow[t]{2}{*}{ pld3 } & $\mathrm{Fw}$ & CCTCTCGCGTTCCTTGATA & 417 & 62.9 \\
\hline & $\mathrm{Rv}$ & CCACGTAAGGGCGATTTAGT & & 62.7 \\
\hline \multirow[t]{2}{*}{ pLd4 } & Fw & GCGGTAACAACATCCGTATC & 508 & 61.8 \\
\hline & Rv & AGTCAGCCCAAGCGACTAAT & & 62.7 \\
\hline \multirow[t]{2}{*}{ pLd5 } & $\mathrm{Fw}$ & AAATACAAGTGTTGAAGGCGTTG & 589 & 63.8 \\
\hline & Rv & ACCTTTGTCTCCAATTTCAGC & & 62.2 \\
\hline \multirow[t]{2}{*}{ pLd6 } & FW & TAAGTGCAACTAAAAGAAATAATAAAGTGCAA & 200 & 65.1 \\
\hline & Rv & TTGCTGATGATTGTACCAGCTAAAAC & & 65.8 \\
\hline \multirow[t]{2}{*}{ pLd7 } & $\mathrm{FW}$ & TGGGCATCTAGATAATCTGACGACATCTGT & 596 & 71.3 \\
\hline & Rv & CGACATTGACTCCCCAAAAACCAAAAATGA & & 75.3 \\
\hline \multirow[t]{2}{*}{ pLd8 } & FW & CCCAGTTGATTTAGAATTAGCTGAAGAATA & 588 & 65.8 \\
\hline & Rv & AGATAGGTTGCATCCAAGATAAATTTGTTA & & 65.9 \\
\hline \multirow[t]{2}{*}{ pLd9 } & FW & TAGTCGCTGGCAAATTTTACAATCA & 323 & 67.0 \\
\hline & Rv & CTTTGGGGGTTGCTTTAGAATCAAT & & 67.5 \\
\hline \multirow[t]{2}{*}{ pLd10 } & $\mathrm{Fw}$ & ACGCTTGAACCCCATCTTGG & 255 & 68.3 \\
\hline & Rv & TCGTCCCAAACGGTTTACCC & & 67.8 \\
\hline \multirow[t]{2}{*}{ pLd11 } & Fw & TTCAATGAATGGCTCGGAAGAA & 388 & 67.6 \\
\hline & Rv & TाTCGGCACAGGAGCAACAT & & 67.9 \\
\hline \multirow[t]{2}{*}{ pLd12 } & $\mathrm{Fw}$ & GAAAACTAATCTAGTACAATCATCAGCAAACTT & 277 & 65.1 \\
\hline & Rv & TाTTACGAGTTATATTGTTTCTAGTCAGATTCTT & & 64.7 \\
\hline
\end{tabular}


stain (Thermo Scientific, USA) and visualised under UV light (Uvitec, UK).

\section{Phenotype testing Growth in LM17}

The maximum growth rate of all variants in LM17 was determined with the two-fold dilution method in a Bioscreen $C$ as described by Biesta-Peters et al. [69]. Briefly, maximum growth rates were determined with three biological replicates and two technical replicates and performing five dilutions per replicate. A single colony was inoculated in LM17 broth and grown overnight at $30{ }^{\circ} \mathrm{C}$. Subsequently, $500 \mu \mathrm{l}$ of the overnight culture was transferred to $9.5 \mathrm{ml}$ fresh LM17 and grown for $3 \mathrm{~h}$ at $30{ }^{\circ} \mathrm{C}$ to have an exponentially growing culture. The exponential culture was diluted $>1000$ times in LM17 medium and two-fold dilutions were made in a 100-well Honeycomb plate, which was incubated for $24 \mathrm{~h}$ at $30^{\circ}$ $C$ with measurements of the optical density at $600 \mathrm{~nm}$ every $5 \mathrm{~min}$. Before each measurement, the plate was shaken for $15 \mathrm{~s}$. The lowest dilution contained $10^{4} \mathrm{CFU} /$ $\mathrm{ml}$ at the start of the incubation. The time to detect an optical density of 0.2 was determined for each dilution from which the maximum growth rate was determined as described by Biesta-Peters [69]. The maximum growth rates correspond to -1 /slope when plotting the natural logarithm of the inoculum concentration versus the time to detection. Representative wells of the highest inoculum concentration were used to compare the growth curves (Fig. 6a).

\section{Growth performance experiments}

The growth performance of variants 48 and 50, differing in plasmid pLd2, was assessed by sequential propagation in mixed cultures. The variants were grown overnight in M17 supplemented with $0.5 \%$ glucose (GM17) and mixed in a ratio $1: 1$ based on optical density measurements at $600 \mathrm{~nm}$ in GM17 supplemented with $0.035 \mathrm{mM} \mathrm{CdCl} 2$. Subsequently, the culture was incubated at $30{ }^{\circ} \mathrm{C}$ and propagated every $48 \mathrm{~h}$ at $1 \%$ inoculation level $(100 \mu \mathrm{l}$ added to $10 \mathrm{ml}$ fresh medium) for 4 times. To determine the ratio of the variants at the end of the propagation ( 27 generations), appropriate dilutions of samples were plated on GM17 agar and incubated for 3 days at $30{ }^{\circ} \mathrm{C}$. Subsequently, the plasmid content was determined of approximately 20 single colonies in three steps: i) DNA extraction, ii) PCR, and iii) gel electrophoresis. DNA was extracted from single colonies by a lysis treatment followed by DNA extraction using the InstaGene ${ }^{\text {Tm }}$ Matrix (Bio-Rad, USA). Colonies were incubated for $30-45 \mathrm{~min}$ at $37{ }^{\circ} \mathrm{C}$ in $200 \mu$ lysis buffer consisting of $20 \mathrm{mM}$ Tris- $\mathrm{HCl}, 2 \mathrm{mM}$ EDTA and $1 \mathrm{mg} / \mathrm{ml}$ lysozyme ( $\mathrm{pH}$ 8.0). Subsequently, samples were centrifuged at $13800 \times g$ for $2 \mathrm{~min}$ and washed with phosphate buffer saline. The pellets were then treated with the InstaGene ${ }^{\mathrm{Tm}}$ Matrix (Bio-Rad, USA) according to the manufacturer's procedure using $100 \mu \mathrm{l}$ matrix instead of $200 \mu \mathrm{l}$. PCR and gel electrophoresis were performed as explained for the screening of the plasmid content. We used pLd2 to distinguish variant 48 and 50 and pLd1 was used as positive control for a successful DNA extraction.

\section{Additional file}

Additional file 1: Figure S1. Summary of sequencing attempts. Figure S2. PCR products confirming the presence of the 12 plasmids in L. lactis FM03P. Figure S3. Multiple sequence alignment of repB promoters of theta-type replication plasmids in L. lactis FM03P. Figure S4. Multiple alignment of RepB amino acid sequences of theta-type replication plasmids of L. lactis FM03P. (PDF 1657 kb)

\section{Abbreviations}

AT: Acetyltransferase; bp: Base pairs; dso: Double-stranded origin; EPS: Exopolysaccharide; GT: Glycosyltransferase; Opp: Oligopeptide permease; Pfam: Protein family; PLD: Phospholipase D; PTS: Phosphotransferase system; RCR: Rolling-circle replication; TRD: Target recognition domain

\section{Acknowledgements}

We thank Mette Nørtoft Kristensen for isolating the strain.

\section{Funding}

This work was financially supported by Arla Foods (Aarhus, Denmark). The funder had no role in the study design, data collection and analysis or preparation of the manuscript.

\section{Availability of data and materials}

The nucleotide sequence of the chromosome and plasmids of L. lactis FM03P has been deposited at GenBank under accession numbers CP020604 to CP020611, MF150536, MF150537, MG813924, MG813925 and MG813926.

\section{Authors' contributions \\ $\mathrm{OM}$ and EJS designed the experiments, OM performed the bioinformatic analyses, OM, EDS and SH performed the experiments, OM wrote the manuscript, OM, EJS and TA revised the manuscript. All authors read and approved the final manuscript.}

Ethics approval and consent to participate Not applicable.

Consent for publication

Not applicable.

\section{Competing interests}

The authors declare that they have no competing interests.

\section{Publisher's Note}

Springer Nature remains neutral with regard to jurisdictional claims in published maps and institutional affiliations.

Received: 23 January 2018 Accepted: 9 August 2018

Published online: 17 August 2018

\section{References}

1. Cavanagh D, Fitzgerald GF, McAuliffe O. From field to fermentation: the origins of Lactococcus lactis and its domestication to the dairy environment. Food Microbiol. 2015;47:45-61.

2. Leroy F, De Vuyst L. Lactic acid bacteria as functional starter cultures for the food fermentation industry. Trends Food Sci Technol. 2004;15(2):67-78.

3. Klijn N, Weerkamp AH, de Vos WM. Detection and characterization of lactose-utilizing Lactococcus spp. in natural ecosystems. Appl Environ Microbiol. 1995;61(2):788-92. 
4. Nomura M, Kobayashi M, Narita T, Kimoto-Nira H, Okamoto T. Phenotypic and molecular characterization of Lactococcus lactis from milk and plants. Appl Microbiol. 2006;101(2):396-405.

5. Sandine W, Radich P, Elliker P. Ecology of the lactic streptococci. A review. J Milk Food Technol. 1972;35(3):176-85.

6. Fallico V, McAuliffe O, Fitzgerald GF, Ross RP. Plasmids of raw milk cheese isolate Lactococcus lactis subsp. lactis biovar diacetylactis DPC3901 suggest a plant-based origin for the strain. Appl Environ Microbiol. 2011;77(18): 6451-62.

7. Kelly WJ, Ward LJ, Leahy SC. Chromosomal diversity in Lactococcus lactis and the origin of dairy starter cultures. Genome Biol Evol. 2010;2:729-44.

8. Passerini D, Beltramo C, Coddeville M, Quentin Y, Ritzenthaler P, DaveranMingot M-L, Le Bourgeois P. Genes but not genomes reveal bacterial domestication of Lactococcus lactis. PLoS One. 2010;5(12):e15306.

9. Salama MS, Musafija-Jeknic T, Sandine WE, Giovannoni SJ. An ecological study of lactic acid bacteria: isolation of new strains of Lactococcus including Lactococcus lactis subspecies cremoris. J Dairy Sci. 1995;78(5):1004-17.

10. Siezen RJ, Starrenburg MJ, Boekhorst J, Renckens B, Molenaar D, van Hylckama Vlieg JE. Genome-scale genotype-phenotype matching of two Lactococcus lactis isolates from plants identifies mechanisms of adaptation to the plant niche. Appl Environ Microbiol. 2008;74(2):424-36.

11. Mills S, McAuliffe OE, Coffey A, Fitzgerald GF, Ross RP. Plasmids of lactococci-genetic accessories or genetic necessities? FEMS Microbiol Rev. 2006;30(2):243-73.

12. Kobayashi M, Nomura M, Fujita Y, Okamoto T, Ohmomo S. Influence of lactococcal plasmid on the specific growth rate of host cells. Lett Appl Microbiol. 2002;35(5):403-8

13. van Mastrigt $\mathrm{O}$, Abee T, Smid EJ. Complete genome sequences of Lactococcus lactis subsp. lactis bv. diacetylactis FM03 and Leuconostoc mesenteroides FM06 isolated from cheese. Genome Announc. 2017:5(28):e00633.

14. Aziz RK, Bartels D, Best AA, DeJongh M, Disz T, Edwards RA, Formsma K, Gerdes S, Glass EM, Kubal M, et al. The RAST server: rapid annotations using subsystems technology. BMC Genomics. 2008;9:75.

15. del Solar G, Giraldo R, Ruiz-Echevarría MJ, Espinosa M, Díaz-Orejas R. Replication and control of circular bacterial plasmids. Microbiol Mol Biol Rev. 1998;62(2):434-64

16. Ainsworth S, Stockdale S, Bottacini F, Mahony J, van Sinderen D. The Lactococcus lactis plasmidome: much learnt, yet still lots to discover. FEMS Microbiol Rev. 2014;38(5):1066-88

17. Khan SA. Rolling-circle replication of bacterial plasmids. Microbiol Mol Biol Rev. 1997;61(4):442-55.

18. Seegers JF, Bron S, Franke CM, Venema G, Kiewiet R. The majority of lactococcal plasmids carry a highly related replicon. Microbiology. 1994; 140(6):1291-300.

19. Novick RP. Plasmid incompatibility. Microbiol Rev. 1987;51(4):381.

20. Francia MV, Varsaki A, Garcillán-Barcia MP, Latorre A, Drainas C, de la Cruz F. A classification scheme for mobilization regions of bacterial plasmids. FEMS Microbiol Rev. 2004;28(1):79-100.

21. van Kranenburg R, de Vos WM. Characterization of multiple regions involved in replication and mobilization of plasmid pNZ4000 coding for exopolysaccharide production in Lactococcus lactis. J Bacteriol. 1998; 180(20):5285-90.

22. Zhang S, Meyer R. The relaxosome protein MobC promotes conjugal plasmid mobilization by extending DNA strand separation to the nick site at the origin of transfer. Mol Microbiol. 1997;25(3):509-16.

23. Perwez T, Meyer RJ. Stabilization of the relaxosome and stimulation of conjugal transfer are genetically distinct functions of the R1162 protein MobB. J Bacteriol. 1999;181(7):2124-31.

24. Kelleher P, Bottacini F, Mahony J, Kilcawley KN, van Sinderen D. Comparative and functional genomics of the Lactococcus lactis taxon; insights into evolution and niche adaptation. BMC Genomics. 2017;18(1):267.

25. Marty-Teysset C, Lolkema JS, Schmitt P, Divies C, Konings WN. Membrane potential-generating transport of citrate and malate catalyzed by Citp of Leuconostoc mesenteroides. J Biol Chem. 1995;270(43):25370-6.

26. Bandell M, Lhotte ME, Marty-Teysset $C$, Veyrat A, Prévost H, Dartois V, Diviès C, Konings WN, Lolkema JS. Mechanism of the citrate transporters in carbohydrate and citrate cometabolism in Lactococcus and Leuconostoc species. Appl Environ Microbiol. 1998;64(5):1594-600.

27. García-Quintáns N, Magni C, de Mendoza D, López P. The citrate transport system of Lactococcus lactis subsp. lactis biovar diacetylactis is induced by acid stress. Appl Environ Microbiol. 1998;64(3):850-7.
28. de Felipe FL, Magni C, de Mendoza D, López P. Citrate utilization gene cluster of the Lactococcus lactis biovar diacetylactis: organization and regulation of expression. Mol Gen Genet. 1995;246(5):590-9.

29. Drider D, Bekal S, Prevost H. Genetic organization and expression of citrate permease in lactic acid bacteria. Genet Mol Res. 2004;3(2):273-81.

30. Smith MR, Hugenholtz J, Mikóczi P, Deree E, Bunch AW, Debont JAM. The stability of the lactose and citrate plasmids in Lactococcus lactis subsp lactis biovar diacetylactis. FEMS Microbiol Lett. 1992;96(1):7-11.

31. van Mastrigt O, Mager EE, Jamin C, Abee T, Smid EJ. Citrate, low pH and amino acid limitation induce citrate utilisation in Lactococcus lactis biovar diacetylactis. Microb Biotechnol. 2018;11(2):369-80.

32. Aleksandrzak-Piekarczyk T, Kok J, Renault P, Bardowski J. Alternative lactose catabolic pathway in Lactococcus lactis IL1403. Appl Environ Microbiol. 2005; 71(10):6060-9.

33. van Rooijen RJ, Gasson MJ, De Vos WM. Characterization of the Lactococcus lactis lactose operon promoter: contribution of flanking sequences and LacR repressor to promoter activity. J Bacteriol. 1992;174(7):2273-80.

34. van Rooijen RJ, de Vos WM. Molecular cloning, transcriptional analysis, and nucleotide sequence of $l a c R$, a gene encoding the repressor of the lactose phosphotransferase system of Lactococcus lactis. J Biol Chem. 1990;265(30): 18499-503.

35. Tynkkynen S, Buist G, Kunji E, Kok J, Poolman B, Venema G, Haandrikman A. Genetic and biochemical characterization of the oligopeptide transport system of Lactococcus lactis. J Bacteriol. 1993;175(23):7523-32.

36. Smid EJ, Poolman B, Konings WN. Casein utilization by lactococci. Appl Environ Microbiol. 1991;57(9):2447-52

37. McKay LL, Baldwin KA. Plasmid distribution and evidence for a proteinase plasmid in Streptococcus lactis C2. Appl Microbiol. 1975;29(4):546-8.

38. Bachmann H, Molenaar D, Kleerebezem M, van Hylckama Vlieg JET. High local substrate availability stabilizes a cooperative trait. ISME J. 2011;5(5):929-32.

39. Erkus O, de Jager VCL, Spus M, van Alen-Boerrigter IJ, van Rijswijck IMH, Hazelwood L, Janssen PWM, van Hijum SAFT, Kleerebezem M, Smid EJ. Multifactorial diversity sustains microbial community stability. ISME J. 2013; 7(11):2126-36.

40. Murray NE. Type I restriction systems: sophisticated molecular machines (a legacy of Bertani and Weigle). Microbiol Mol Biol Rev. 2000;64(2):412-34.

41. Cowan GM, Gann AAF, Murray NE. Conservation of complex DNA recognition domains between families of restriction enzymes. Cell. 1989; 56(1):103-9.

42. O'Sullivan D, Twomey DP, Coffey A, Hill C, Fitzgerald GF, Ross RP. Novel type I restriction specificities through domain shuffling of $\mathrm{HsdS}$ subunits in Lactococcus lactis. Mol Microbiol. 2000;36(4):866-75.

43. Schouler C, Gautier M, Ehrlich SD, Chopin M-C. Combinational variation of restriction modification specificities in Lactococcus lactis. Mol Microbiol. 1998;28(1):169-78.

44. Roberts RJ, Vincze T, Posfai J, Macelis D. REBASE - a database for DNA restriction and modification: enzymes, genes and genomes. Nucleic Acids Res. 2014;43(D1):D298-D9.

45. Letunic I, Doerks T, Bork P. SMART: recent updates, new developments and status in 2015. Nucleic Acids Res. 2014;43(D1):D257-D60

46. Pingoud A, Wilson GG, Wende W. Type II restriction endonucleases-a historical perspective and more. Nucleic Acids Res. 2014;42(12):7489-527.

47. Ofir G, Melamed S, Sberro H, Mukamel Z, Silverman S, Yaakov G, Doron S, Sorek R. DISARM is a widespread bacterial defence system with broad antiphage activities. Nat Microbiol. 2017:1:90-8.

48. Deng Y-M, Harvey ML, Liu C-Q, Dunn NW. A novel plasmid-encoded phage abortive infection system from Lactococcus lactis biovar. diacetylactis. FEMS Microbiol Lett. 1997;146(1):149-54.

49. Broadbent JR, McMahon DJ, Welker DL, Oberg CJ, Moineau S. Biochemistry, genetics, and applications of exopolysaccharide production in Streptococcus thermophilus: a review. J Dairy Sci. 2003;86(2):407-23.

50. Zeidan AA, Poulsen VK, Janzen T, Buldo P, Derkx PM, Øregaard G, Neves AR. Polysaccharide production by lactic acid bacteria: from genes to industrial applications. FEMS Microbiol Rev. 2017:41(Supp_1):S168-200.

51. Schirawski J, Hagens W, Fitzgerald GF, van Sinderen D. Molecular characterization of cadmium resistance in Streptococcus thermophilus strain 4134: an example of lateral gene transfer. Appl Environ Microbiol. 2002; 68(11):5508-16.

52. Liu C-Q, Khunajakr N, Chia LG, Deng Y-M, Charoenchai P, Dunn NW. Genetic analysis of regions involved in replication and cadmium resistance of the plasmid pND302 from Lactococcus lactis. Plasmid. 1997;38(2):79-90. 
53. O' Sullivan D, Ross RP, Twomey DP, Fitzgerald GF, Hill C, Coffey A. Naturally occurring lactococcal plasmid pAH90 links bacteriophage resistance and mobility functions to a food-grade selectable marker. Appl Environ Microbiol. 2001:67(2):929-37.

54. Endo G, Silver S. CadC, the transcriptional regulatory protein of the cadmium resistance system of Staphylococcus aureus plasmid pl258. J Bacteriol. 1995;177(15):4437-41.

55. Tsai KJ, Linet AL. Formation of a phosphorylated enzyme intermediate by the cadA Cd ${ }^{2+}$-ATPase. Arch Biochem Biophys. 1993;305(2):267-70.

56. Crupper SS, Worrell V, Stewart GC, landolo JJ. Cloning and expression of cadD, a new cadmium resistance gene of Staphylococcus aureus. J Bacteriol. 1999;181(13):4071-5

57. Niegowski D, Eshaghi S. The CorA family: structure and function revisited. Cell Mol Life Sci. 2007;64(19):2564

58. Kehres DG, Lawyer $\mathrm{CH}$, Maguire ME. The CorA magnesium transporter gene family. Microb Comp Genomics. 1998;3(3):151-69.

59. Nierop Groot MN, Klaassens E, de Vos WM, Delcour J, Hols P, Kleerebezem M. Genome-based in silico detection of putative manganese transport systems in Lactobacillus plantarum and their genetic analysis. Microbiology. 2005;151(4):1229-38

60. Richer E, Courville P, Bergevin I, Cellier MFM. Horizontal gene transfer of "prototype" Nramp in bacteria. J Mol Evol. 2003:57(4):363-76.

61. Woufers JA, Sanders J-W, Kok J, de Vos WM, Kuipers OP, Abee T. Clustered organization and transcriptional analysis of a family of five csp genes of Lactococcus lactis MGI363. Microbiology. 1998;144(10):2885-93.

62. Booth IR, Edwards MD, Black S, Schumann U, Miller S. Mechanosensitive channels in bacteria: signs of closure? Nat Rev Microbiol. 2007;5(6):431-40.

63. Wright GD. Bacterial resistance to antibiotics: enzymatic degradation and modification. Adv Drug Deliv Rev. 2005;57(10):1451-70.

64. Siezen RJ, Renckens B, van Swam I, Peters S, van Kranenburg R, Kleerebezem M, de Vos WM. Complete sequences of four plasmids of Lactococcus lactis subsp. cremoris SK11 reveal extensive adaptation to the dairy environment. Appl Environ Microbiol. 2005;71(12):8371-82.

65. Tanous C, Chambellon E, Yvon M. Sequence analysis of the mobilizable lactococcal plasmid pGdh442 encoding glutamate dehydrogenase activity. Microbiology. 2007;153(5):1664-75.

66. Nickels $\mathrm{C}$, Leesment $\mathrm{H}$. Method for the differentiation and qualitative determination of starter bacteria. Milchwissenschaft. 1964;19:374-8.

67. Terzaghi BE, Sandine WE. Improved medium for lactic streptococci and their bacteriophages. Appl Microbiol. 1975;29(6):807-13.

68. Fujita $Y$, Okamoto T, Irie R. Protoplast rormation and regeneration in lactic streptococci. Agric Biol Chem. 1983;47(9):2103-5.

69. Biesta-Peters EG, Reij MW, Joosten H, Gorris LG, Zwietering MH. Comparison of two optical-density-based methods and a plate count method for estimation of growth parameters of Bacillus cereus. Appl Environ Microbiol. 2010;76(5):1399-405

Ready to submit your research? Choose BMC and benefit from:

- fast, convenient online submission

- thorough peer review by experienced researchers in your field

- rapid publication on acceptance

- support for research data, including large and complex data types

- gold Open Access which fosters wider collaboration and increased citations

- maximum visibility for your research: over $100 \mathrm{M}$ website views per year

At $\mathrm{BMC}$, research is always in progress.

Learn more biomedcentral.com/submissions 